Джеджера Ольга

ст. викладач кафедри вікової та педагогічної психології Рівненського державного гуманітарного університету http://orcid.org/0000-0001-5471-703X

Юрчук Олексій канд.пед.наук, доцент кафедри педагогіки і психології (дошкільної та корекційної) імені проф. Поніманської T.I. Рівненського державного гуманітарного університету http://orcid.org/ 0000-0002-4764-1783 DOI https://doi.org/10.35619/praprv.v1i15.183

\title{
ОСОБЛИВОСТІ ПЕРЕЖИВАННЯ СУБ'ЄКТИВНОГО ЕМОЦИЙНОГО СТАНУ ЗДОБУВАЧАМИ ВИЩОЇ ОСВІТИ ПІД ЧАС ДИСТАНЦЙНОГО НАВЧАННЯ В УМОВАХ ПАНДЕМІї COVID-19
}

\begin{abstract}
Анотація. У статті розглядаються особливості переживання суб'єктивного емоиійного стану здобувачів вищої освіти під час дистанщійного навчання в умовах пандемії COVID-19. На основі аналізу наукових праџь виявлено, щзо в умовах карантину, введеного внаслідок пандемії коронавірусної хвороби, відбуваються відчутні зміни в емоційних переживаннях здобувачів вищої освіти, спричинені як кризовою пандемічною ситуацією, так і необхідністю переходу студентів денної форми навчання на дистанційне навчання.
\end{abstract}

Висвітлено результати проведеного дослідження, яке підтверджує теоретичні висновки авторів. Зокрема констатовано, щу більще третини студентів (учасників дослідження) визначались низьким рівнем самопочуття, активності, настрою, переживаючи при цьому підвищену тривожність, агресивність; їм була притаманна ригідність та стан фрустрації. 3'ясовано, щьо переважна більшість здобувачів вищої освіти не вважають дистанційну форму навчання ефективною для себе, оскільки їм бракує ефективної комунікації, збільшується їх навантаження, змінюється режим, погіршується самопочуття через втому та одноманітність. Суб' єктивна самооцінка емочійних, фізичних та когнітивних змін продемонструвала підвищення рівня емоційного напруження, тривоги, відчуття провини, розвиток відчуття соціального відчуження, брак спілкування, постійні зміни настрою, труднощі з концентрацією уваги, та самоорганізацією, погіршення загального фізичного самопочуття через постійну втому, проблеми з травленням, змінами апетиту, зниження якості сну. Виявлено кореляційну пряму залежність між рівнями тривожності, фрустрованості, ригідності та агресивності; протилежну залежність між рівнями самопочуття та активності і фізичних та когнітивних змін.

Ключові слова: емоційне переживання, емочійний стан, переживання суб' єктивного емоційного стану, дистаниійне навчання, пандемія, карантин, здобувачі вищої освіти.

Постановка проблеми. У зв'язку зі світовою пандемією та запровадженням карантинних заходів заклади вищої освіти України були змушені повністю або частково переорієнтуватись на засади дистанційного навчання та реалізувати дистанційну комунікацію 3 допомогою дистанційних технологій (платформ та інструментів: Moodle, Google Classroom, Zoom, Skype, Google Suite/Docs тощо), через електронну пошту, месенджери, форуми, чати тощо зі студентами очної і заочної форм навчання.

Попри задекларовані переваги цієї форми навчання (відкритість, доступність, мобільність,гнучкість, оперативність, об' єктивність оцінки знань студентів) (Адамова, 2012, с. 4) вона вносить суттєві зміни у якість і зміст педагогічної взаємодії, зумовлює відрив здобувачів освіти від звичного освітнього середовища, значно скорочує кількість і частоту контактів соціально активних молодих людей та вимагає від них готовності навчатись дистанційно. Таким чином, здобувачі вищої освіти, які звикли до безпосередньої взаємодії 3 
викладачами, потрапили в незвичну для них ситуацію віддаленості у просторі від них, від інших студентів та від своїх закладів, і змушені переорієнтовуватись на спілкування у режимі он-лайн. Це зумовило суттєві зміни у їхній співпраці, пов'язані передусім 3 необхідністю інтенсивного двостороннього використання інформаційно-комунікаційних технологій та засвоєння нових способів навчальної діяльності. У зв'язку з цим, як слушно стверджу Сакало, «під час освіти онлайн, посилилася проблема вигорання, бо в кожного своя реакція на це - від банальної втоми очей до складнощів з освоєнням нових інструментів» (Сакало, 2020), що, на наш погляд, призводить до зростання нервово-психічного напруження усіх учасників освітнього процесу.

Водночас на емоційних станах студентів позначаються ситуація, пов'язана 3 розповсюдженням коронавірусної інфекції, введенням та постійним обговоренням у ЗМІ і в повсякденному спілкуванні особливостей перебігу хвороби, пов'язаних з цим карантинних обмежень, що супроводжується емоційно зарядженим медійним бумом. У таких умовах цілком закономірним $є$ переживання більшістю студентів доволі сильних емоцій, які у певний спосіб позначаються на загальному емоційному стані та на результативності їхнього навчання.

Аналіз останніх досліджень 3 проблеми. Незважаючи на відносну новизну охарактеризованих обставин, актуальність і гострота пов'язаних 3 ним проблем привернула увагу багатьох дослідників і спричинила появу доволі великого числа наукових публікацій. Зокрема викликають інтерес зроблені вченими висновки стосовно наявності і наслідків впливу пандемії COVID-19 на психологічні особливості емоційних переживань людини в карантинних реаліях життя (Анищенко, Вознесенська, Гундертайло, Дятел, Довгань, Дроздов, Зімовін, Ларіна, Коваленко-Кобилянська, Лушин, Малецька, Л. Найдьонова, Новосельська, Рудницька, Савінов, Сиско, Слюсаренко, Тітова, Хаустова, Чабан, Ягілєв та ін.), згідно з якими сьогодні відбувається загострення суспільних психологічних реакцій напруги, тривоги та страху, втрата орієнтирів і планів на майбутнє, що, як наголошує Чабан, може призвести до підвищення гостроти реакції на стрес, депресії, інших емоційних розладів (Чабан, 2020, с. 36), консервації негативних емоцій (Найдьонова, 2020, с. 7) та відповідно позначитись на життєдіяльності загалом та навчальній діяльності студентів зокрема.

Як засвідчують дані психологічних (Бабаєва, Бабанін, Войскунський, Застело, Лукашенко, Луценко, Малінко, Мараховська, Маталига, Підчасов, Г. Ржевський, Л. Ткачук) i педагогічних (Адамова, Бикова, Головачук, Даценко, Захар, Кухаренко, Самойленко, Самолюк, Сиротенко, Швець) досліджень, дистанційне навчання супроводжується досить складними технічними проблемами й особистісними труднощами, оскільки потребує від здобувача вищої освіти достатнього рівня досвіду роботи 3 електронними засобами, готовності до самостійного планування і виконання самостійної роботи та необхідної для цього вольової саморегуляції навчально-пізнавальної діяльності (Ткачук).

Цілком зрозуміло, що для здійснення дистанційного навчання необхідним $\epsilon$ впровадження і використання у вищій школі інформаційно-комунікаційних технологій. Можливості розв'язання цієї проблеми в умовах пандемії коронавірусної хвороби COVID-19 вивчають Бережна, Браммер, Прокопенко, Кларк, Холл. У результаті ними виявлено не тільки переваги, але й недоліки дистанційного навчання, які, на думку С. Бережної та I. Прокопенко спричиняють зокрема психологічні проблеми внаслідок відсутності живого спілкування, неможливості повторного складання пропущених занять, значного збільшення кількості завдань, браку часу на їх виконання, обмеженого доступу до комп'ютера та Інтернету тощо (Бережна, Прокопенко, 2020, с. 134).

Як стверджують Самолюк та Швець, поряд зі значними перевагами дистанційної форми навчання, що розглядається Даценко як форма такої його організації, коли студенти віддалені від викладача у просторі і часі, але можуть підтримувати діалог 3 допомогою засобів комунікації (Даценко, 2017, с. 18), суттєвим іiі недоліком є високий рівень зумовленості особистісними мотивами здобувачів освіти, їх умінням працювати самостійно в умовах відсутності особистісного спілкування з викладачем, що унеможливлює негайне практичне застосування отриманих знань або отримання потрібних консультацій чи 
роз'яснень, а також, що важливо, молодим людям бракує спілкування з іншими студентами, у ході якого вони обмінюються досвідом і емоціями (Самолюк, 2013, с.196).

Відповідно Г. Ржевським було виявлено, що у порівнянні $з$ традиційною формою навчання в умовах дистанційної освіти нижчим є рівень відповідальності та задоволення студентів процесом і результатами навчання, їх ідентифікації з майбутньою професією. Натомість, 3 погляду автора, підвищується рівень тривожності та фрустрованості особистісних освітніх потреб (Ржевський, 2017, с. 219).

Як бачимо, цілком ймовірним є те, що зміна форми навчання на дистанційну може призвести до зміни змісту його регулятивних чинників з боку екзістенційної, потребнісномотиваційної, емоційної особистісних сфер. У зв'язку з цим в освітньому середовищі виникають думки про недостатню ефективність дистанційного навчання студентів очної форми передусім 3 причин недосконалого технічного забезпечення інформаційних комунікацій закладів вищої освіти зі студентами та не завжди оптимального рівня готовності здобувачів освіти до відповідальної співпраці з вивчення навчальних дисциплін.

Мета статті полягає у відображення результатів дослідження, що було проведено для вивчення особливостей переживань суб'єктивного емоційного стану здобувачів вищої освіти під час дистанційного навчання в умовах карантину.

Виклад основного матеріалу дослідження. Погоджуючись з очевидною проблемою впливу депривації звичних умов освітнього середовища на ефективність навчальної діяльності студентів очної форми навчання, бачиться доцільним звернути увагу на ще й на інші особистісні чинники, зумовлені переживаннями у зв'язку з перебуванням на карантині через COVID-19. 3 цією метою нами було проведено дослідження самопочуття, активності, настрою (за методикою Доскіна, Мірошникова), психічних станів (за методикою Айзенка), а також опитування здобувачів вищої освіти щодо їх ставлення до змінених обставин навчання та суб'єктивної оцінки емоційних, фізичних та когнітивних змін.

Експрес-оцінка самопочуття, активності, настрою студентів була здійснена 3 допомогою Методики діагностики самопочуття, активності, настрою ( Доскін, Мірошніков).

У результаті опрацювання отриманих даних було встановлено, що середній рівень самопочуття учасників дослідження становив 4,6 бали, активності $-4,5$ бали, настрою $-5,0$ бали, що свідчило про переважно позитивний стан опитуваних. Проте діапазону нормальних оцінок стану (5,0-5,5 балів) досягав в мінімумі лише показник настрою.

Аналіз отриманих показників дав змогу виявити такі особливості переживання досліджуваними певних емоційних станів. Погане самопочуття спостерігалося у 29,6\% опитаних (див. рис.1).

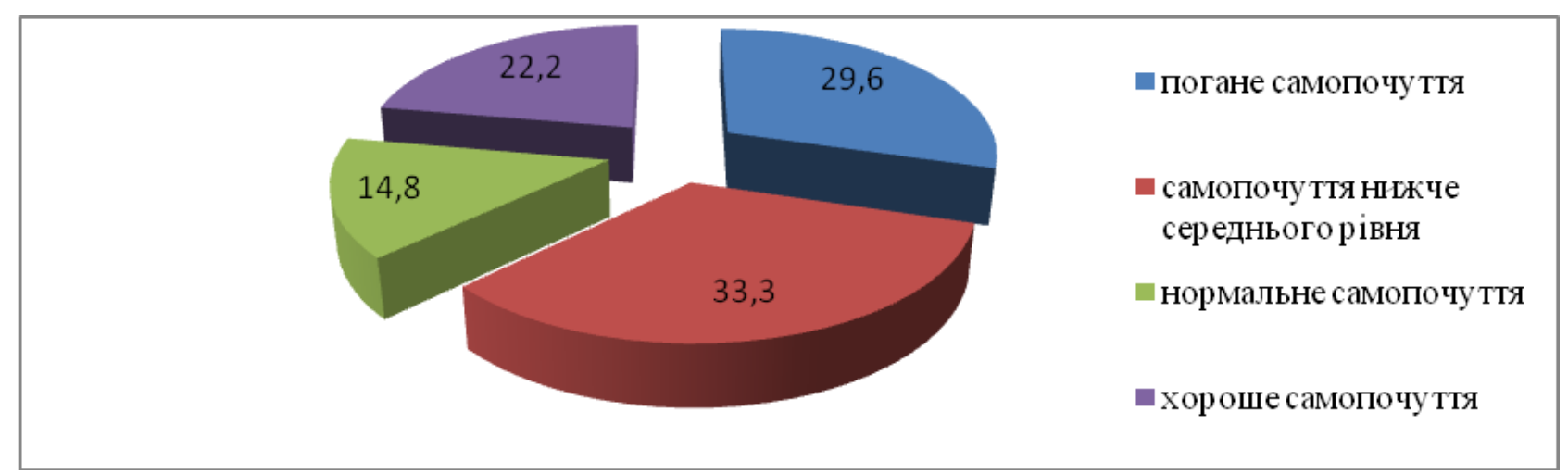

\section{Рис.1. Розподіл респондентів за типами самопочуття (\%)}

Позитивне самопочуття, але із нижчим за середній рівень було констатовано у $33,3 \%$ студентів. Нормальним самопочуттям декларували $14,8 \%$ студентів. Хороше самопочуттям було діагностовано у $22,2 \%$ опитаних 
За критерієм рівня активності наша вибірка розпалася наступним чином. Низький рівень активності був притаманний $37 \%$ опитаних; позитивний, але нижчий за середню норму рівень активності був виявлений у 29,6\% учасників опитування; середній рівень активності було зафіксовано у 29,6\% студентів, а високий рівень активності - в 11,1\% здобувачів вищої освіти (див. рис 2).

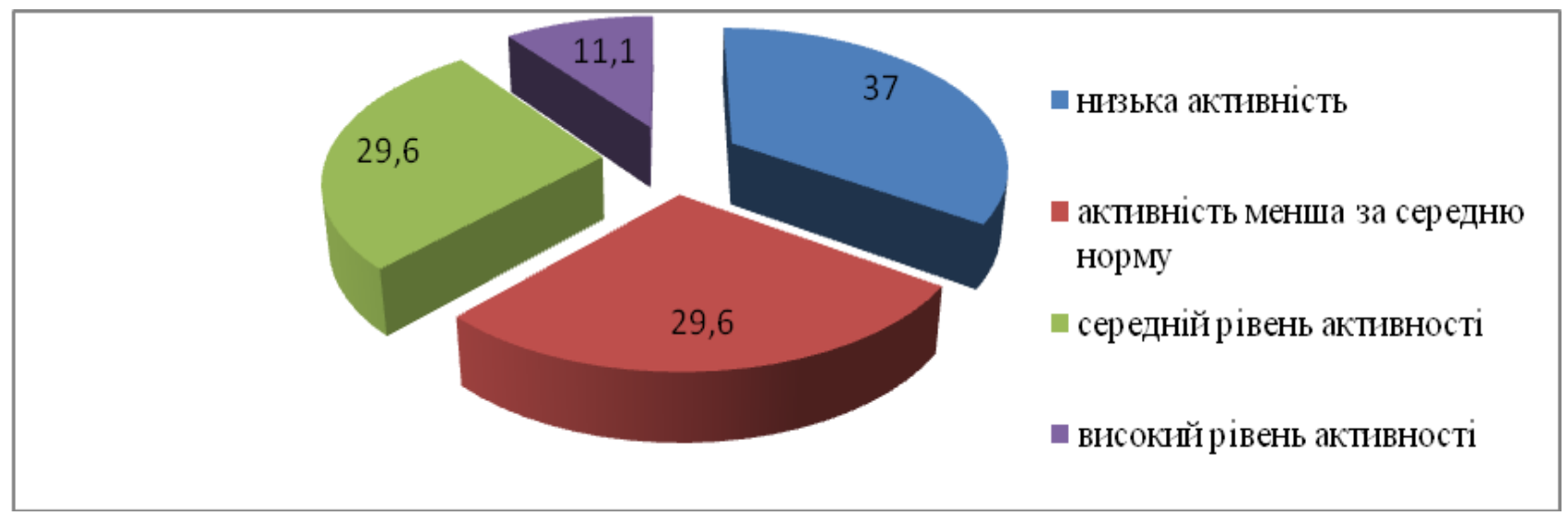

Рис. 2. Розподіл респондентів за рівнями активності (\%)

За критерієм настрою, як довготривалого емоційного стану ми отримали наступні результати: поганий настрій було констатовано в 18,5\% респондентів; позитивний, але нижчий від середнього рівня - в 22,2\% студентів, нормальний настрій - у 25,9\% студентів, хороший настрій - у $33,3 \%$ опитаних

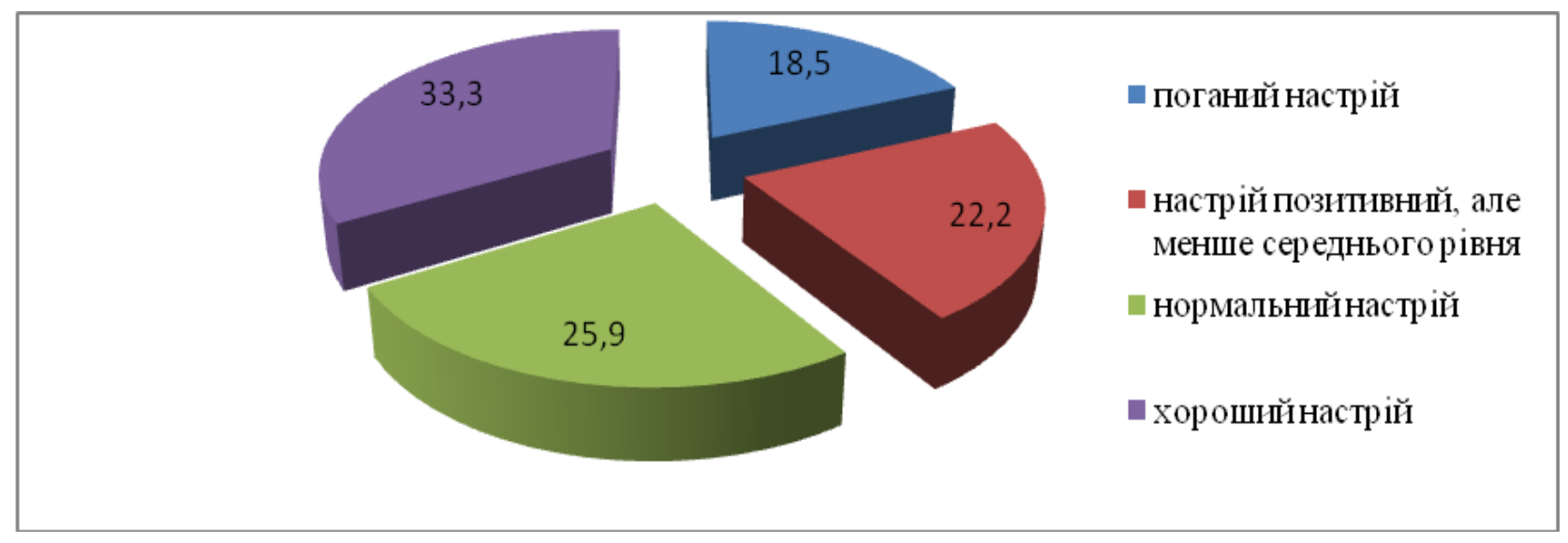

Рис. 3. Розподіл респондентів за рівнями настрою (\%)

Таким чином, було з'ясовано, що більшій частині учасників дослідження були притаманні нижчі середньої норми показники самопочуття (у 62,9\% осіб), знижена активність (у 66,6\% осіб) і водночас, хороший настрій (у 59,2\% осіб).

Отримані результати самооцінки психічних станів, що проводилася за методикою Г. Айзенка, засвідчили переважно середній рівень тривожності, фрустрації, агресивності та ригідності учасників опитування. При цьому досліджувані вище за середній рівень показники було констатовано: тривожності - у 55,4\% респондентів, які мали підвищену схильність до надмірного хвилювання щодо психологічного характеру загрози в ситуації пандемії COVID-19, глибоке відчуття тривоги, безпомічності; фрустрації - у 44,6\% респондентів, що виявлялось у дезорганізації свідомості та діяльності, відчутті безнадійності, втраті перспективи, апатії, порушення власної працездатності та 
результативності; агресивності - у 44,6\% респондентів, котрі переживали спалахи гніву, злоби, відзначались імпульсивністю поведінки; ригідності - у 50,0\% респондентів, які не були готові до перебудови системи власних мотивів навчання та змінити поведінку в нових умовах, фіксували увагу на негативних емоційних переживаннях, можливих невдачах i труднощах. Дослідження суб'єктивної оцінки емоційних, фізичних та когнітивних змін, що визначають якість самопочуття, рівні активності, тривожності, агресивності, фрустрації, ригідності та модальність настрою, притаманних здобувачам вищої освіти під час карантину та дистанційного навчання, проводилось 3 допомогою анкетування.

Дистанційне навчання вважали повністю ефективним 21,8\% опитаних, які вказали на такі ії переваги, як от: можливість вчитись у будь-якому місці та у спокійній обстановці, без відриву від іншої роботи; зменшення рівня стресу; можливість самоорганізуватись, ефективно розподілити свій час; отримання можливості для оволодіння технологіями навчання о-нлайн; вільний графік навчальної роботи; можливість навчатись у комфортних, спокійних домашніх умовах. Водночас $24,1 \%$ судентів вважали таку форму навчання абсолютно неефективною, а 54,1\% 3 них - частково ефективною, що було пов'язано 3 тим, що: не вистачає спілкування 3 групою; існують труднощі у засвоєнні матеріалу поза безпосереднім спілкуванням 3 викладачем, без його пояснень та коментарів в аудиторії; надто багато часу приділяється роботі за комп'ютером; знижується мотивація до навчання. Також переважна більшість респондентів відзначали проблеми 3 інтернет-зв'язком через його погану якість (див. рис. 4).

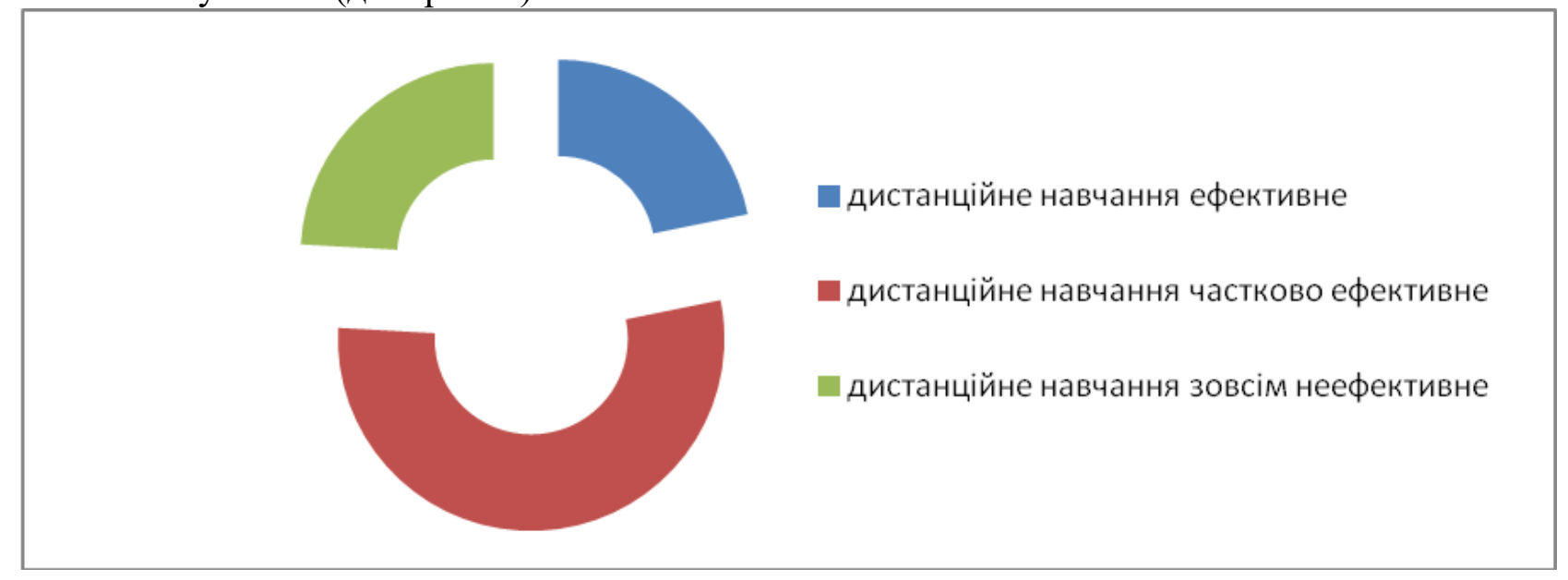

\section{Рис. 4. Розподіл респондентів за ознакою ставлення до ефективності дистанційного навчання (\%)}

Як виявилось, унаслідок впровадження дистанційного навчання у здобувачів вищої освіти змінилося ставлення до власної навчальної діяльності. Так, 35,5\% респондентів вказали на те, що зрозуміли переваги очного навчання, стали відповідальніше виконувати завдання, приділяти більше часу для опрацювання матеріалу. Натомість більше третини студентів $(35,5 \%)$ повідомили про погіршення ставлення до навчання через втрату інтересу, одноманітність, порушення режиму, відсутність адекватного спілкування, перевтому, тривогу, страх пропустити важливі завдання, труднощі в засвоєнні дисциплін через переважно самостійну роботу.

Згідно з результатами опитування самопочуття під час дистанційного навчання в умовах карантину погіршилось у 47,8\% респондентів, а покращилося - у 24,3\% студентів. Стан самопочуття не змінився у $27,9 \%$ опитаних. Причинами погіршення свого самопочуття, що виявлялось у головних та м'язових болях, порушенні роботи серцево-судинної системи, погіршенні зору, безсонні, проблемах із травленням, підвищенні рівня тривожності та інших психосоматичних змінах, труднощах із концентрацією, відчуття втоми тощо, студенти вважають порушення режиму сну та харчування, збільшення навантаження під час опрацювання матеріалу 3 навчальних дисциплін, значне зниження фізичної активності, комунікативну депривацію, труднощі в ефективній організації навчального часу, постійні відволікання, відкладання виконання завдань. Ті респонденти, які відчували покращення 
свого стану, пояснювали його тим, що їм легше i приємніше вчитись у домашніх комфортних умовах, у спокійній обстановці, коли $є$ можливість краще організувати свою роботу, розподілити свій час.

Було виявлено, що здобувачі вищої освіти переживають під час карантину i спричиненого ними дистанційного навчання постійні зміни настрою: часто $(40,6 \%)$, інколи (31,3\%); емоційне напруження: часто - 46,9\%студентів, інколи - у $34,4 \%$ студентів; відчуття соціального відчуження: часто - 31,3\% здобувачів вищої освіти, інколи - 25\% 3 них; сум, відсутність інтересу до життя: часто - 18,8\% опитаних, інколи - у 43,8\% 3 них; занепокоєння, постійну тривогу, почуття провини, нервозність: часто - 37,5\% респондентів, інколи - у 40,6\% досліджуваних. Фізичні зміни, які опитувані зафіксували упродовж останнього часу, виявлялись у: низькому рівні енергії, постійній втомі: часто - у 37,5\% студентів, інколи - у $34,4 \% 3$ них; головних болях, м'язовій напрузі: часто - 34,4\% здобувачів освіти, інколи - у $53,8 \%$ студентів; проблемах із травленням - у 62,6\% опитаних; частому болі у грудях, прискореному серцебитті - у 31,2\% респондентів; виражених змінах апетиту (насамперед у зниженні апетиту) - у 40,6\% досліджуваних; частому безсонні, кошмарах - 40,7\% молодих людей. Когнітивні зміни проявлялися у зниженні концентрації уваги (65,4\% осіб), хаотичності думок (68,8\% респондентів), забудькувасті, дезорганізації (59,4\% студентів), прокрастинації, постійному відкладанні та перенесенні справ, труднощів у прийнятті рішень (65,7\% опитуваних).

Аналіз результатів дослідження емоційних, фізичних та когнітивних змін, які мали місце під час вимушеного карантину та переходу на дистанційне навчання, дав змогу згрупувати їх причини таким чином (табл. 1).

Таблиця 1.

Показники емоційних, фізичних та когнітивних змін здобувачів вищої освіти під час дистанційного навчання в умовах пандемії COVID-19

\begin{tabular}{|l|l|c|}
\hline \multirow{5}{*}{ Емоційні зміни } & \multicolumn{1}{|c|}{ Ознаки } & $\begin{array}{c}\text { Кількісні } \\
\text { показники (\%) }\end{array}$ \\
\cline { 2 - 3 } & Зміни настрою & 71,9 \\
\cline { 2 - 3 } & Емоційне напруження & 81,3 \\
\cline { 2 - 3 } & Відчуття соціального відчудження & 56,3 \\
\cline { 2 - 3 } & Сум, відсутність інтересу до життя & 62,6 \\
\cline { 2 - 3 } & Занепокоєння, тривога, відчуття провини & 78,1 \\
\hline \multirow{5}{*}{ Фізичні зміни } & Низький рівень енергії, постійна втома & 71,9 \\
\cline { 2 - 3 } & Часті головні болі, м’язова напруга & 88,2 \\
\cline { 2 - 3 } & Проблеми з травленням & 62,6 \\
\cline { 2 - 3 } & Частий біль у грудях, прискорене серцебиття & 31,2 \\
\cline { 2 - 3 } & Виражені зміни апетиту & 40,6 \\
\cline { 2 - 3 } & Часте безсоння, нічні кошмари & 40,7 \\
\hline & Труднощі з концентрацією уваги & 65,5 \\
\cline { 2 - 3 } & Хаотичність думок & 68,8 \\
\cline { 2 - 3 } & Забудькуватість, дезорганізація & 59,4 \\
\cline { 2 - 3 } & Прокастинація, постійне відкладання та перенесення & 65,7 \\
\hline & справ, труднощі у прийнятті рішень & \\
\hline
\end{tabular}

Після проведеного дослідження було здійснено статистичний аналізу його результатів за допомогою коефіцієнта кореляції $\mathrm{r}$-Пірсона (при $\mathrm{n}=56$, достовірно значимий рівень $\mathrm{p}<0,05$ ) (див. табл.2). 
Зв'язок міэс психічними станами, самопочуттям, активністю та настроєм $i$ Таблиия 2 емоційними, фізичними та когнітивними змінами у здобувачів вищяої освіти під час дистанційного навчання в умовах пандемії COVID-19

\begin{tabular}{|l|c|c|c|c|c|c|}
\hline & $\begin{array}{c}\text { фрустра- } \\
\text { ція }\end{array}$ & $\begin{array}{c}\text { агресив- } \\
\text { ність }\end{array}$ & $\begin{array}{c}\text { ригід- } \\
\text { ність }\end{array}$ & $\begin{array}{c}\text { емоційні } \\
\text { зміни }\end{array}$ & $\begin{array}{c}\text { фізичні } \\
\text { зміни }\end{array}$ & $\begin{array}{c}\text { когнітивні } \\
\text { зміни }\end{array}$ \\
\hline тривожність & 0,6172 & 0,2426 & 0,5622 & $-0,0030$ & 0,0858 & 0,0319 \\
\hline фрустрація & - & 0,2821 & 0,5705 & 0,0443 & 0,0050 & 0,0615 \\
\hline агресивність & - & - & 0,5317 & 0,1300 & 0,1300 & 0,0344 \\
\hline ригідність & - & - & - & $-0,0225$ & $-0,0459$ & 0,0257 \\
\hline емоційні зміни & - & - & - & - & 0,3601 & 0,2438 \\
\hline фізичні зміни & - & - & - & - & - & 0,2437 \\
\hline самопочуття & 0,1885 & 0,1253 & 0,2160 & $-0,1171$ & $-0,2949$ & $-0,3675$ \\
\hline активність & 0,1100 & 0,1760 & 0,1425 & $-0,2034$ & $-0,2972$ & $-0,3526$ \\
\hline настрій & 0,0840 & $-0,0572$ & 0,0216 & 0,1109 & $-0,0638$ & 0,0280 \\
\hline
\end{tabular}

Завдяки проведеному аналізу було виявлено, що підвищення рівня тривожності сприяє підвищенню рівня фрустрації та агресивності, а підвищення рівня ригідності підвищенню рівня тривожності, фрустрованості та агресивності. Також було встановлено прямий взаємозв'язок між емоційними та фізичними, а також когнітивними змінами здобувачів вищої освіти під час дистанційного навчання. Статистично підтверджено, що погіршення самопочуття, як і зниження активності викликає негативні зміни у емоційному, фізичному стані, погіршується якість когнітивних процесів.

Висновки і перспективи подальших розвідок. Здійснене дослідження дало змогу виявити зміни в емоційних станах здобувачів вищої освіти, які навчалися дистанційно в умовах пандемії COVID-19. Такі зміни, що виявлялись у певному погіршенні самопочуття, зниженні рівня активності, погіршенні настрою, посиленні тривожності, фрустрованості, ригідності, призводили й до фізичних та когнітивних змінами. Таким чином, ймовірним $\epsilon$ вплив суб' єктивного емоційного та фізичного стану здобувачів вищої освіти на ефективність навчальної діяльності під час дистанційного навчання в умовах карантину, що спонукає до подальшого дослідження взаємозв'язку досліджуваних факторів та визначення рівня взаємовпливу.

\section{СПИСОК ПОСИЛАНЬ}

Адамова, I. (2012). Дистанційне навчання: сучасний погляд на переваги та проблеми. Витоки педагогічної майстерності, 10, 3-6.

Даценко, Г., \& Сузанська, 3. (2017). Дистанційне навчання як засіб стимулювання самоосвіти. В Дистаниійне навчання як сучасна освітня технологія: Матеріали міжвузівського вебінару (м. Вінниия, 31 берез. 2017 р.) (с. 17-20). Вінниця: ВТЕI KHTEУ.

Найдьонова, Л. А. (2020). Медіапсихологічні феномени інфодемії. Досвід переживання пандемії covid-19: дистаниійні психологічні дослідження, дистаниійна психологічна підтримка: Матеріали онлайн-семінарів. Київ: ІСПП НАПН України. Взято з: http://ispp.org.ua/wp-content/uploads/Static/dosvid_onl-sem_23-04-20_and_15-0520_ncov19.pdf

Ржевський, Г. М. (2017). Дистанційна форма навчання в сучасних умовах: психологопедагогічні особливості. Науковий вісник Національного університету біоресурсів $i$ природокористування України. Серія «Педагогіка. Психологія. Філософія», 259, 214221.

Сакало, С. (2020). Про дистаниійну освіту в університетах в умовах карантину. Взято з: https://zn.ua/ukr/EDUCATION/viklik-yakogo-ne-mozhna-ne-priynyati-347904_.html. 
Самолюк, Н. (2013). Актуальність і проблемність дистанційного навчання. Нова педагогічна думка, 11, 193-197.

Ткачук, Л. В. Психологічні особливості дистанщійного навчання як перспективної освітньої технологіi. Взято 3: http://www.zippo.net.ua/data/files/KafPsihol/NavchRobota/ lvtkachuk_02.pdf.

Чабан, О. С. (2020). Психічне здоров'я в період пандемії COVID-19 (особливості психологічної кризи, тривоги, страху та тривожних розладів): реалії та перспективи. НейроNEWS: психоневрологія та нейропсихіатрія, 3(114), 26-36.

Berezhna, S., \& Prokopenko, I. (2020). Higher Education Institutions in Ukraine during the Coronavirus, or COVID-19. Outbreak: New Challenges vs New Opportunities. Revista Romaneasca pentru Educatie Multidimensionala, 12, 130-135.

\section{REFERENCES}

Adamova, I`. (2012). Distanczi jne navchannya: suchasnij poglyad na perevagi ta problemi [Distance learning: a modern look at the benefits and challenges]. Vitoki pedagogi chnoyi majsternosti , 10, 3-6. [in Ukrainian].

Daczenko, G., \& Suzans`ka, Z. (2017). Distanczi`jne navchannya yak zasi`b stimulyuvannya samoosvi ti [Distance learning as a means of stimulating self-education.]. V Distanczi jne navchannya yak suchasna osvi tnya tekhnologi`ya: Materi ali mi zhvuzi vs`kogo vebi`naru (m. Vi`nniczya, 31 berez. 2017 r.) (s. 17-20). Vi`nniczya: VTEI KNTEU. [in Ukrainian].

Najd`onova, L. A. (2020). Medi`apsikhologi`chni fenomeni i`nfodemi`yi [Mediapsychological phenomena of infodemia]. Dosvi'd perezhivannya pandemi yi covid-19: distanczi jni psikhologi`chni doslidzhennya, distanczi`jna psikhologi`chna pi`dtrimka: Materi`ali onlajn-semi`nari $v$. Kyiv: ISPP NAPN Ukrayini. Vzyato z: http://ispp.org.ua/wpcontent/uploads/Static/dosvid_onl-sem_23-04-20_and_15-05-20_ncov19.pdf. [in Ukrainian].

Rzhevs`kij, G. M. (2017). Distanczi`jna forma navchannya v suchasnikh umovakh: psikhologopedagogi 'chni osoblivosti [Distance learning in modern conditions: psychological and pedagogical features]. Naukovij vi`snik Naczi`onal’nogo uni`versitetu bi`oresursi`v $i$ prirodokoristuvannya Ukrayini. Seri ya «Pedagogi`ka. Psikhologi ya. Fi losofi ya», 259, 214-221. [in Ukrainian].

Sakalo, Ye. (2020). Pro distanczi`jnu osvi`tu v uni`versitetakh v umovakh karantinu [About distance education in universities under quarantine]. Vzyato $\mathrm{z}$ : https://zn.ua/ukr/EDUCATION/viklik-yakogo-ne-mozhna-ne-priynyati-347904_.html. [in Ukrainian].

Samolyuk, N. (2013). Aktual`ni`st` i` problemni`st' distanczi jnogo navchannya [Relevance and problems of distance learning]. Nova pedagogi chna dumka, 11, 193-197. [in Ukrainian].

Tkachuk, L. V. Psikhologi`chni osoblivosti distanczi jnogo navchannya yak perspektivnoyi osvi`tnoyi tekhnologi'yi [Psychological features of distance learning as a promising educational technology]. Vzyato z: http://www.zippo.net.ua/data/files/KafPsihol/NavchRobota/lvtkachuk_02.pdf. [in Ukrainian].

Chaban, O. S. (2020). Psikhi`chne zdorov'ya v peri`od pandemi`yi COVID-19 (osoblivosti` psikhologi chnoyi krizi, trivogi, strakhu ta trivozhnikh rozladi`v): reali yi ta perspektivi [Mental health during the COVID-19 pandemic (features of psychological crisis, anxiety, fear and anxiety disorders): realities and prospects]. NejroNEWS: psikhonevrologi ya ta nejropsikhi atri'ya, 3(114), 26-36. [in Ukrainian].

Berezhna, S., \& Prokopenko, I. (2020). Higher Education Institutions in Ukraine during the Coronavirus, or COVID-19, Outbreak: New Challenges vs New Opportunities. Revista Romaneasca pentru Educatie Multidimensionala, 12, 130-135. [in English]. 


\title{
PECULIARITY OF EXPERIENCE OF SUBJECTIVE EMOTIONAL EXPERIENCES BY APPLICANTS FOR HIGHER EDUCATION DURING DISTANCE LEARNING IN A COVID-19 PANDEMIC
}

Olha Dzhedzhera senior lecturer at the Department of Age and Educational Psychology Rivne State University for the Humanities http://orcid.org/0000-0001-5471-703X

Oleksii Yurchuk

Candidate of Pedagogical Sciences, Associate Professor at the Department of Pedagogy and Psychology (Preschool and Correctional) named after Professor T.Ponimanska, Rivne State University for the Humanities, http://orcid.org/0000-0002-4764-1783

DOI https://doi.org/10.35619/praprv.v1i15.183

\begin{abstract}
The article considers the peculiarities of experiencing the subjective emotional state of higher education students during distance learning in the context of the COVID-19 pandemic.

Based on the analysis of scientific works, it was found that in the conditions of quarantine imposed as a result of the coronavirus pandemic, there are significant changes in the emotional experiences of higher education students, caused by both the crisis pandemic situation and the need transition of full-time students to distance learning.

The results of the study are highlighted, which confirms the theoretical conclusions of the authors. In particular, it was stated that more than a third of students (study participants) were characterized by a low level of well-being, activity, mood, while experiencing increased anxiety, aggression; they were characterized by rigidity and a state of frustration. It has been found that the vast majority of higher education students do not consider distance learning to be effective for themselves, as they lack effective communication, increase their workload, change their regime, and feel worse due to fatigue and monotony. Subjective self-assessment of emotional, physical and cognitive changes showed increased levels of emotional stress, anxiety, guilt, development of feelings of social exclusion, lack of communication, constant mood swings, difficulty concentrating and self-organization, deterioration of general physical well-being due to constant fatigue, problems with digestion, changes in appetite, decreased sleep quality. A direct correlation was found between the levels of anxiety, frustration, rigidity and aggression; the opposite relationship between levels of well-being and activity and physical and cognitive changes.
\end{abstract}

Key words: emotional experience, emotional condition, experience of subjective emotional condition, distance learning, pandemic, quarantine, applicants for higher education. 